\title{
The Application of Beyond Centers and Circle Time Approach
}

\author{
Mursyid
}

Received: 20052016 / Accepted: 25052016 / Published online: 13122016 ๑) 2016 Association of Indonesian Islamic Kindergarten Teachers Education Study Program

\begin{abstract}
Abstrad This research used qualitative descriptive approach which lead into a field research. BCCT learning in RA N galian was regarded as an effective data obtained. It was 73 percent stated agree and the other of 27 percent stated very agree. Constitutionally, supporting factor in applying BCCT method appears in some aspects, such as the location, the headmaster's competence, and teachers' competence. As for the implementation in RA (PAUD) of $\mathrm{N}$ galian District, most of 67 percent of respondents stated agree and the other of 18 percent of respondents stated disagree. The role of teacher as inspiration for their students and as center of learning was not applied yet holistically. The data obtained, it was almost 45 percent of respondents stated agree and 10 percent stated very agree. It means the role of teacher as inspiration was not applied. M eanwhile the weaknesses factor of BCCT learning in RA (PAUD) of N galian district was the lack of time management in implementing BCCT method. This took effect in the learning process. The obtained data showed 45 percent stated agree and 9 percent stated very agree. It means that the time management was most recommended in order the BCCT learning could run well. Because of seeing the allotted time was limited, it made students were forced to accomplish some steps being passed. So that, the time management was required.
\end{abstract}

Key words the application of BCCT, the supporting factor, the weaknesses factor.

\begin{abstract}
Abstrak Penelitian ini menggunakan pendekatan deskriptif kualitatif yang diarahkan ke suatu penelitian lapangan (field research). Pembelajaran BCCT di RA Kecamatan Ngalian terbilang efektif data yang diperoleh, $73 \%$ setuju dan $27 \%$ lainya menyatakan sangat setuju. Faktor pendukung dan penghambat. Secara normatif, faktor pendukung dalam penerapan metode BCCT, muncul dari beberapa aspek, antara lain: lokasi sekolah, kompetensi kepala sekolah, dan kompetensi tenaga pendidik. Adapun implementasinya di RA (PAUD) Kecamatan Ngalian hampir $67 \%$ responden menyatakan setuju dan $18 \%$ menyatakan setuju. Dan yang tidak menyetujui ada $18 \%$. Peranan pendidik sebagai insipirator bagi anak didik dan sebagai pusat pembelajaran masih belum diaplikasikan secara penuh. Data yang diperoleh, hampir $45 \%$ responden menyatakan setuju dan 10\% menyatakan sangat setuju, yang artinya pendidik sebagai inspirator tidak dilaksanakan. A dapun yang menjadi faktor penghambat lain pembelajaran BCCT di RA (PAUD) Kecamatan N galian adalah kurangnya manajemen waktu dal am penerapan metode BCCT, hal ini sangat berpengaruh dalam proses pembelajaran. Data yang diperoleh, $45 \%$ setuju dan $9 \%$ sangat setuju. Artinya, manajemen waktu ini sangat untuk dilakukan agar pembelajaran BCCT dapat berjalan dengan baik. Karena, melihat keterbatasan waktu yang ada (satu setengah jam) membuat anak harus terforsir dalam menyelesaikan beberapa tahapan yang harus dilalui. Sehingga, manajemen waktu sangat diperlukan.
\end{abstract}

Kata Kunci: A plikasi BCCT, faktor pendukung, faktor penghambat. 


\section{Pendahuluan}

Di Indonesia dewasa ini pengembangan dan pembinaan potensi anak usia dini tengah mendapatkan perhatian serius dari sejumlah pihak khususnya dari pemerintah. Karena patut disadari bahwa anak usia dinilah yang akan menjadi generasi penerus masadepan. Untuk mewujudkan generasi yang unggul dan tangguh serta mampu bersaing menghadapi kehidupan di masa yang akan datang, perlu upaya pengembangan dan pembinaan anak yang sesuai dengan masa pertumbuhan dan perkembangannya. Beberapa aspek perkembangan yang vital untuk diperhatikan pada anak usia dini yaitu nilai agama dan moral, kognitif, bahasa, sosial emosional, serta fisik motorik. Agar semua aspek ini dapat berkembang dengan baik, maka diperlukan suatu sistem pengembangan dan pembinaan anak usia dini yang berkualitas, salah satu komponen sistem pengembangan tersebut adalah melaksanakan proses pembelajaran melalui bermain.

Pendekatan Beyond Centers and Circles Time (BCCT) memandang bermain sebagai media yang tepat dan satu-satunya media pembelajaran anak karena disamping menyenangkan, bermain dalam setting pendidikan dapat menjadi media untuk berpikir aktif dan kreatif. Banyak dijumpai di lapangan penerapan pendekatan BCCT khususnya RA, guru pembimbing masih menggunakan metode satu arah di mana guru mengajarkan sesuai dengan kemampuan guru atau program belajar tidak melihat kemampuan anak sehingga anak mengalami kejenuhan saat belajar, ketergantungan, kurang mandiri dan tidak kreatif. Tentu, karena pembelajaran hanya berpusat pada guru. Pembelajaran yang baik untuk anak usia dini harus menyesuaikan dengan kebutuhan dan perkembangan anak. Pada masa ini anak suka bermain. Dengan menerapkan belajar melalui bermain, proses pembelajaran akan lebih mengena. Sebab mereka terlibat dan merasakan secara langsung.

Jika melihat hakikat dari Pendidikan Anak Usia Dini (PAUD), pendidikan ini diselenggarakan dengan tujuan untuk memfasilitasi pertumbuhan dan perkembangan anak secara menyeluruh atau menekankan pada pengembangan seluruh aspek kepribadian anak. Maka PAUD memberi kesempatan bagi anak untuk mengembangkan kepribadian dan potensi secara maksimal. Atas dasar ini, lembaga PAUD perlu menyediakan berbagai kegiatan yang dapat mengembangkan berbagai aspek perkembangan seperti kognitif, bahasa, sosial emosional, motorik, moral, serta agama (Rahmat, 2003:16).

Pendekatan BCCT materi yang dikembangkan berupa sentra. Sentra dibuat berdasarkan kebutuhan anak dengan mengobservasi setiap perkembangan anak. Jadi kebutuhan sentra mungkin tidak sama di setiap lembaga pendidikan tergantung kesiapan perangkat dan tenaga pengajar yang ada., adapun ke tujuh sentra yang dikembangkan dalam pembelajaran adalah sentra bahan alam, sentra main peran mikro atau makro, sentra balok, sentra persiapan, sentra iman \& taqwa (Religion Center), sentra seni dan kreatifitas.

Dengan mengetahui tentang pendekatan BCCT perlu diadakan penelitian di PAUD (RA) Kecamatan N galian bagaimana aplikasi pendekatan BCCT, sehingga menjadi harapan sekolahsekolah PAUD (RA) di Kecamatan Ngalian secara keseluruhan menerapkan pendekatan 
tersebut. Penelitian ini penting sekali untuk dilakukan karena melalui Pendekatan BCCT anak dapat melejitkan kecerdasan, menanamkan nilai-nilai dasar (nasionalisme, agama, etika, moral dan sosial), pengembangan dasar (penglihatan, pendengaran, sentuhan, gerakan, pendampingan, kasih sayang).

\section{Pembahasan}

Dalam teorinya, BCCT banyak sekali memberikan peningkatan aspek kognitif, afektif dan psikomotorik. Pada aspek kognitif, akan terlihat pada anak seperti; Anak dapat lebih mudah menangkap apa yang disampaikan kepada mereka dan lebih mudah memahami tentang apa saja yang kita jelaskan dan menjadi wahana yang sangat menyenangkan untuk mereka, anak akan lebih memiliki rasa ingin tahu, anak lebih mudah dalam memecahkan persoalan, membangun pengetahuan anak melalui pengalaman main, dapat membangun pengetahuan anak sehingga mendorong munculnya kreativitas anak.

Terkait dengan aspek kognitif yang terlihat pada pendekatan ini, tentu tidak lepas dari naluriah kecerdasan yang dibawa oleh peserta didik. Maka, Howard Gardner sebagaimana dikutip oleh Anita Yus menyatakan bahwa pada hakikatnya setiap anak ialah cerdas. Gardner melihat kecerdasan dari berbagai dimensi. Setiap kecerdasan yang dimiliki akan dapat mengantarkan anak mencapai kesuksesan. Pendidik/guru perlu memfasilitasi setiap kecerdasan yang dimiliki anak dalam pembelajaran dan kegiatan belajar di antaranya:

Gardner mengemukakan kecerdasan dalam beberapa dimensi, yaitu:

1. Kecerdasan bahasa (Linguistik) berkaitan dengan keterampilan dan persepsi mengel ola kata dan bahasa. Yakni kemampuan menggunakan kata-kata secara efektif.

2. Kecerdasan logika - matematika berkaitan dengan keterampilan dan persepsi dalam bidang angka (Numerik) dan alasan logis.

3. Kecerdasan music berkaitan dengan keterampilan dan persepsi dalam bidang music dan suara

4. Kecerdasan gerak tubuh (kinestesis) berkaitan dengan ketrampilan dan persepsi dalam bidang mengolah dan mengendalikan gerak anggota tubuh.

5. Kecerdasan gambar dan ruang (visual-spasial) berkaitan dengan keterampilan dan persepsi dalam bidang permainan, garis, warna, bentuk, dan ruang.

6. Kecerdasan diri (intrapersonal) berkaitan dengan keterampilan dan persepsi dalam bidang kesadaran dan pengenalan terhadap diri sendiri.

7. Kecerdasan berbaur (interpersonal) berkaitan dengan keterampilan dan persepsi dalam bidang membina hubungan dengan orang lain.

8. Kecerdasan alami (naturalis) berkaitan dengan keterampilan dan persepsi dalam bidang yang berhubungan dengan alam dan lingkungan sekitar.

9. Kecerdasan rohani (spiritual) berkaitan dengan keterampilan dan persepsi dalam bidang mengolah rohani. 
Kemudian dalam aspek afektif sangat terlihat kelebihan dari pendekatan ini. Di antaranya; A nak menjadi lebih aktif dan dapat melakukan kegiatan/belajar sesuai dengan minat anak. Sehingga kreatifitasnya akan melejit, kegiatan yang terinci dengan jelas membuat anak dapat bersosialisasi dengan baik pada saat bermain dengan teman-teman/bekerjasama, Anak lebih semangat karena pembelajaran dilakukan dengan metode demonstrasi, membuat anak lebih menyenangkan dalam belajar sambil bermain, tidak monoton dan diam ditempat, tidak membatasi gerak A nak sesuai dengan apa yang diinginkan, anak lebih aktif dan antusias dalam mengikuti pembelajaran.

Selanjutnya dalam aspek psikomotorik, jelas terlihat ketika aspek kognitif-afektif dimiliki oleh anak maka psikomotoriknya ikut berjalan. Ini dapat dilihat dari kemampuan anak dalam fisik misalnya anak dapat berlari untuk mencari solusi dari permasalahan. Kemudian anak lebih mandiri dan bertanggungjawab pada hal yang dilakukan di sentra karena dalam aturan BCCT ada kemandirian dan tanggungjawab.

Sebenarnya kelebihan atau manfaat yang terlihat dalam pendekatan ini tidak hanya pada anak. Tetapi pada guru; guru dapat memberikan inovasi dalam pembelajaran sehingga anak akan merasa senang dan guru pasti akan membuat inovasi atau pengembangan lebih agar anak didiknya bisa semakin senang saat pembelajaran berlangsung. Selain itu anak lebih mudah dikondisikan dan Kemampuan anak lebih mudah terpantau, lebih terfokus dan penilaian lebih terperinci dan fokus. Sehingga pada akhirnya hasil pembelajaran lebih maksimal.

Jadi, jika dilihat dari kelebihan dari pendekatan ini dalam aspek kognitif, afektif dan psikomotorik jelas sekali terlihat. Dan ketiganya, apabila dipandang dari teorinya Howard Gardner tentang kercerdasan yang pada dasarnya teori ini Bloom ini semuanya adalah kecerdasan (selama dilakukan oleh peserta didik). Artinya, jika peserta didik melakukan hal demikian, maka kecerdasan ini akan melekat pada diri anak.

Selain kelebihan, tentu ada kekurangan dalam pendekatan BCCT. Dari beberapa angket yang disebar, sarana prasarana adalah kelemahan yang banyak ditemui. Sarana dan prasarana ini merupakan tanggung jawab dari pihak sekolah atau pengelola. Bagi sekolahan yang "mampu" tentu persoalan ini tidak menjadi problem. Maka, untuk mencapai hasil yang maksimal diperlukan "injeksi dana" dari pemerintah untuk penggadaan alat-alat atau perabot yang berhubungan dengan pendekatan BCCT ini.

Dalam pandangan guru RA di Semarang, juga ditemukan beberapa kelemahan dalam pendekatan ini. Diantaranya; dalam pendekatan ini anak jadi lebih suka bermain disentrasentra kegiatan daripada mendengarkan apa yang dijelaskan oleh pendidik guru. $\mathrm{Hal}$ ini jelas akan "mematikan" perhatian anak pada guru. Banyaknya ragam main yang harus disiapkan sehingga guru harus selalu kreatif dalam mencipta ragam main, guru capek.

Selanjutnya, ada beberapa sekolah yang tidak sesuai dengan kebutuhan anak didik dalam sentra. Artinya, perbandingan guru dan anak di sekolah biasanya guru utama dan guru pendamping bisa mengajar 30-40 anak di tiap kelas. Sedangkan disentra, jumlah anak terbatas. 
Kemudian seringkali dalam ranah praktisnya, adanya beberapa jenis main yang disiapkan sering membuat guru tidak menyadari apakah anak-anak suka dengan permainan yang disiapkan oleh guru. M eskipun pada dasarnya, guru harus melihat apakah permainan tersebut menyenangkan atau tidak. atau mungkin, guru perlu menanyakan langsung kepada anak didiknya apakah mereka senang dan nyaman dengan pendekatan BCCT ini.

Selain di atas, kelemahan yang terjadi tidak semua peserta didik mampu menyelesaikan penugasan-penugasan dari guru. Ini karena keterbatasan waktu yang telah ditetapkan atau dijadwalkan oleh pihak sekolah.

Kesuksesan dan kegagalan dalam BCCT sangat tergantung pada beberapa komponen pandidikan dalam RA di Kecamatan N galian. Baik SDM, media maupun masyarakat. Hampir semua responden menjawab, faktor pendukung paling banyak disebut adalah media untuk menggunakan aplikasi pembelajaranya.

Penelitian sebelumnya yang berjudul "Implementasi Beyond Centers and Circles Time (BCCT) approach untuk menumbuhkan aspek M oral Keagamaan pada A nak U sia Dini (Studi Komparasi antara TK dan RA di Kota Semarang)" yang ditulis oleh Mursid dkk, memang media paling mendukung dalam pelaksanaan BCCT. Dan dalam penelitian sebelumya memang ratarata Raudlatul Athfal (RA) kurang memiliki fasilitas yang cukup sesuai standar pelaksanaan Beyond Center and Circle Time (BCCT), sehingga guru mengalami kesulitan dalam praktik pembelajaran melalui Beyond Center and Circle Time (BCCT) ini. Hal lain yang yang mendukung adalah Sumber Daya Manusia (SDM) guru di Raudlatul Athfal (RA) yang relatif jarang mendapatkan kesempatan (terlebih secara rutin) untuk meningkatkan kemampuannya. Sehingga, pelaksanaan BCCT di RA Kota Semarang kurang maksimal.

Kemudian dalam hasil temuan di lapangan kurang siapnya kepala sekolah dan guru, kurangnya sarana dan prasarana, kurangnya alat permainan, kurangnya kerjasama antara sekolah dengan orang tua. M enjadi penghambat pelaksanaan BCCT. Jadi, faktor penghambat ini tidak hanya terjadi saat di lembaga pendidikan (RA) tetapi juga karakteristik anak yang dibawa oleh rumah. Artinya, sikap dan kecerdasan anak dalam menangkap intruksi dari pendidik menjadi faktor pendukung agar pelaksanaan BCCT ini berjalan dengan baik. Dengan kata lain, intruksi dari guru tentang pelaksanaan BCCT ini tidak akan sampai memahamkan murid ketika.

\section{Faktor Pendukung Dan Penghambat BCCT}

Secara normatif, faktor pendukung dalam penerapan metode BCCT, muncul dari beberapa aspek, antara lain: lokasi sekolah, kompetensi kepala sekolah, dan kompetensi tenaga pendidik. Adapun implementasinya di RA (PAUD) Kecamatan Ngalian hampir 67\% responden menyatakan setuju dan 18\% menyatakan setuju. Dan yang tidak menyetujui ada 18\%. Dari responden yang tidak menyetujui bahwa; lokasi sekolah, kompetensi kepala sekolah, dan kompetensi tenaga pendidik adalah salah satu hal yang mendukung dimungkin karena hal yang 
terpenting yang mendukung suksesnya pembelajaran ini adalah pada murid. Tidak pada guru lokasi sekolah, kompetensi kepala sekolah, dan kompetensi tenaga pendidik.

$\mathrm{Hal}$ yang juga diamini atau disetujui oleh responden, dimana lingkungan sekolah yang sangat kondusif ketika proses pembelajaran berlangsung, sehingga hasil pembelajaran dapat dicapai dengan optimal. Dan semua responden menyatakan setuju.

Peran kepala sekolah dalam mewujudkan penerapan metode BCCT, dengan melihat pentingnya pendidikan bagi anak usia dini melalui perkembangan anak secara optimal. Kepala sekolah harus menjadi motivator bagi pendidik sehingga dapat meningkatkan mutu serta kualitas pendidik dan lembaga pendidikan.

Selain itu, pendidik sebagai fasilitator, mediator, inspirator, kordinator, modelling dan labelling harus menjadi jembatan anak didik menuju keberhasilan. Pendidik harus profesional dan berkompeten dalam lingkup pendidikan serta perkembangan anak. Pendidik harus memiliki kemampuan untuk memahami secara utuh tentang penerapan metode BCCT ini, sehingga sangat menguasai tahap-tahap perkembangan anak. Pendidik harus memiliki kesamaan visi dalam mengembangkan pendidikan untuk anak usia dini. Persiapan pendidik secara matang dalam menyajikan dan mengemas materi pembelajaran.

Peran pendidik di atas, sepenuhnya disetujui oleh responden. Bahkan hampir semuanya sangat menyetujui. $\mathrm{H}$ al ini dianggap wajar karena pendidik yan sebagai orang yang memberikan instruksi dalam pembelajaran ini harus bisa menjalankan segala yang dibutuhkan dalam pembelajaran BCCT ini. Selanjutnya, pembelajaran BCCT ini dapat berjalan dengan baik jika sarana dan prasarana yang dapat menunjang proses pembelajaran terpenuhi. Data yang ditemui di lapangan, menyatakan bahwa menyetujui bahkan sangat menyetujui sarana dan prasarana sangat mendukung pembelajaran ini. Sebab sarana dan prasarana dalam pembelajaran dapat membantu merangsang perkembangan anak usia dini. Seperti yang telah dijelaskan diatas bahwa problem dalam penerapan metode BCCT muncul dari berbagai aspek, antara lain: kepala sekolah, pendidik, sarana prasarana, waktu dan orang tua. Maka menjadi pendidik yang harus kreatif, inovatif dan menjadi inspirator bagi peserta didik (kreativitas pendidik). Saat pembelajaran berlangsung, yang menjadi problem adalah mengubah karakter pendidik merupakan kendala awal dalam menerapkan metode BCCT. Dalam hal ini, responden $36 \%$ tidak menyetujui. Dan selebihnya menyetujui. Ini menunjukkan bahwa karakter pendidik harus dirubah. Artinya, pendidik yang biasanya tidak menggunakan metode pembelajaran ini sedikitdemi sedikit harus mau melakasanakan pembelajaran ini.

Peranan pendidik sebagai insipirator bagi anak didik dan sebagai pusat pembelajaran masih belum diaplikasikan secara penuh. Data yang diperoleh, hampir $45 \%$ responden menyatakan setuju dan 10\% menyatakan sangat setuju, yang artinya pendidik sebagai inspirator tidak dilaksanakan. Padahal, dalam pembelajaran berlangsung jika pendidik tidak bisa menjadi inspirator maka imajinasi siswa dalam belajar, kreatifitas siswa tidak akan terbangun.

Belum tersedianya kurikulum yang tetap untuk anak usia dini. Responden yang menyatakan setuju $56 \%$ dan sangat setuju $9 \%$. Selebihnya menyatakan setuju. Dari data yang 
ada, dapat ditarik kesimpulan mengapa guru tidak bisa menjadi inspirator karena tidak tersedianya kurikulum yang dapat memberikan gambaran yang jelas terkait dengan pembelajaran BCCT ini.

A dapun yang menjadi faktor penghambat lain pembelajaran BCCT di RA (PAUD) Kota Semarang adalah kurangnya manajemen waktu dalam penerapan metode BCCT, hal ini sangat berpengaruh dalam proses pembelajaran. Data yang diperoleh, $45 \%$ setuju dan $9 \%$ sangat setuju. A rtinya, manajemen waktu ini sangat untuk dilakukan agar pembelajaran BCCT dapat berjalan dengan baik. Karena, melihat keterbatasan waktu yang ada (satu setengah jam) membuat anak harus terforsir dalam menyelesaikan beberapa tahapan yang harus dilalui. Sehingga, manajemen waktu sangat diperlukan.

Tetapi perlu diketahui bahwa, pembelajaran ini menurut data lapangan yang ada, ternyata waktu yang ada tidak membuat anak terfosir aktifitasnya. $\mathrm{Hal}$ ini terlihat dari data yang ada bahwa responden tidak setuju $63 \%$ dan sangat tidak setuju $9 \%$ selebihnya menyatakan setuju. M eskipun kegiatan pembelajaran terlihat terburu-buru, karena dengan waktu yang ada harus menyelesaikan empat tahapan, yaitu: pijakan lingkungan main, pijakan sebelum main, pijakan saat main, dan pijakan sesudah main. Ini dapat dilihat dari $63 \%$ responden menyatatakan setuju, dan selebihnya tidak setuju.

Faktor penghambat lainya adalah kurangnya koordinasi antara pendidik dan orang tua dalam pembelajaran. Karena selain pendidik, orang tua harus memahami secara penuh metode pembelajaran anak, mengingat waktu kegiatan anak lebih banyak di habiskan di lingkungan rumahnya. Dalam hal ini responden $63 \%$ menyatakan setuju dan $18 \%$ menyatakan setuju. A rtinya, hubungan orangtua dan pendidik anak di sekolah perlu ditingkatkan.

Pembelajaran BCCT di RA Kecamatan N galian terbilang efektif data yang diperoleh, 73\% setuju dan $27 \%$ lainya menyatakan sangat setuju. $\mathrm{Hal}$ demikian ada karena kurikulum BCCT padadasarnya diarahkan untuk membangun pengetahuan anak, yang digali secara individual oleh anak itu sendiri melalui berbagai pengalaman main di sentra-sentra kegiatan, sehingga mendorong kreativitas anak.

Tetapi bermain dalam metode BCCT di RA Kecamatan Ngalian bukan satu-satunya wahana yang paling tepat dalam pembelajaran anak, meskipun secara normatif wahana ini sangat menyenangkan serta dapat memicu anak untuk berfikir aktif dan kreatif. Data yang diperoleh di lapangan, 27\% tidak setuju dan selebihnya menyetujui. Sekali lagi, ini artinya pembelajaran ini bukan satu-satunya wahana yang paling tepat dalam pembelajaran anak.

\section{Kesimpulan}

Pembelajaran BCCT di RA Kecamatan N galian terbilang efektif data yang diperoleh, $73 \%$ setuju dan $27 \%$ lainya menyatakan sangat setuju. Hal demikian ada karena kurikulum BCCT pada dasarnya diarahkan untuk membangun pengetahuan anak, yang digali secara individual oleh anak itu sendiri melalui berbagai pengalaman main di sentra-sentra kegiatan, sehingga mendorong kreativitas anak. 
Tetapi bermain dalam metode BCCT di RA Kecamatan Ngalian bukan satu-satunya wahana yang paling tepat dalam pembelajaran anak, meskipun secara normatif wahana ini sangat menyenangkan serta dapat memicu anak untuk berfikir aktif dan kreatif. Data yang diperoleh di lapangan, 27\% tidak setuju dan selebihnya menyetujui. Sekali lagi, ini artinya pembelajaran ini bukan satu-satunya wahana yang paling tepat dalam pembelajaran anak. Faktor pendukung dan penghambat. Secara normatif, faktor pendukung dalam penerapan metode BCCT, muncul dari beberapa aspek, antara lain: lokasi sekolah, kompetensi kepala sekolah, dan kompetensi tenaga pendidik. Adapun implementasinya di RA (PAUD) Kecamatan $\mathrm{N}$ galian hampir $67 \%$ responden menyatakan setuju dan $18 \%$ menyatakan setuju. Dan yang tidak menyetujui ada 18\%. Dari responden yang tidak menyetujui bahwa; lokasi sekolah, kompetensi kepala sekolah, dan kompetensi tenaga pendidik adalah salahsatu hal yang mendukung dimungkin karena hal yang terpenting yang mendukung suksesnya pembelajaran ini adalah pada murid. Tidak pada guru lokasi sekolah, kompetensi kepala sekolah, dan kompetensi tenaga pendidik. Adapun yang menjadi faktor penghambat lain pembelajaran BCCT di RA (PAUD) Kecamatan Ngalian adalah kurangnya manajemen waktu dalam penerapan metode BCCT, hal ini sangat berpengaruh dalam proses pembelajaran. Data yang diperoleh, $45 \%$ setuju dan $9 \%$ sangat setuju. Artinya, manajemen waktu ini sangat untuk dilakukan agar pembelajaran BCCT dapat berjalan dengan baik. Karena, melihat keterbatasan waktu yang ada (satu setengah jam) membuat anak harus terforsir dalam menyelesaikan beberapa tahapan yang harus dilalui. Sehingga, manajemen waktu sangat diperlukan.

\section{Referensi}

Aisyah, Siti. 2008. Perkembangan dan Konsep Dasar Pengembangan Anak Usia Dini, Jakarta: U niversitas Terbuka.

Aqib, Zainal. 2009. Belajar dan Pembelajaran di Taman kanak-kanak., (Bandung: Yrama Widya.

A rikunto, Suharsimi. 1990. M anajemen Penelitian. Jakarta: Rineka Cipta. . 1993. Prosedur Penelitian Suatu Pendekatan Praktik. Jakarta: Rineka Cipta.

A smani, Jamal Ma'mur. 2010. Buku Pintar Playgroup. Yogyakarta: Buku Biru.

Desmita. 2009. Psikologi Perkembangan. Bandung: PT. Remaja Rosdakarya.

Isjoni. 2010. M odel Pembelajaran AUD. Bandung: Alfabeta.

J. M oeloeng, Lexy. 2002. M etode Penelitian Kualitatif. Bandung: Remaja Rosdakarya.

Ma'mur Asmani, Jamal. 2009. Manajemen Strategis Pendidikan Anak Usia Dini. Yogyakara: Diva Press,

Mursid. Modul Mengelola Bahan Main Yang Tepat, Disampaikan Pada Mata Kuliah Pendidikan Anak Usia Dini

Padmonodewo, Soemarti. 2003. Pendidikan Anak Prasekolah. Jakarta: PT. Rineka Cipta. 
Ratna M egawangi, et. Al. 2004. Pendidikan yang Patut dan M enyenangkan: Penerapan Teori Developmentally A ppropriate Practice (DAP). Jakarta: Indonesian Heritage Fondation.

Rebecca Novick, Ph.D., 1996. Developmentally Appropriate and Culturally Responsive Education:Theory in Practice. Oregon: Child and Family Program.

Salim, Agus. 2006. Teori dan Paradigma Penelitian Sosial. Yogyakarta: Toara W acana.

Santoso, Soegeng dan Prof. Dr., M.Pd., 2004 Pendidikan Anak Usia Dini, (Jakarta: Citra Pendidikan.

Soepartinah Pakasi. 1985. Anak Dan Perkembangannya, Pendekatan Psiko-Paedagogis, Terhadap Geneasi M uda. Jakarta: Gramedia.

Sugiyono, Metode Penelitian Pendidikan: Pendekatan Kuantitatif, Kualitatif, dan R \& D (Bandung: Alfabeta, 2010)

Sugiyono. 2010. M etode Penelitian Pendidikan. Bandung : Alfabeta.

Sumadi Suryabrata, Psikologi Pendidikan, (Jakarta: CV . Rajawali, 1988).

Sutrisno Hadi, M.A., Prof., Drs., M etodologi Research I, (Yogyakarta: Fak. Psikologi UGM, 1986).

Suyanto, Slamet. 2005. Dasar-D asar Pendidikan A nak U sia Dini. Yogyakarta: Hikayat. UU RI Nomor 20 Tahun 20003 T entang Sisdiknas. 2008. Bandung: Citra U mbara.

Yusuf LN, Syamsul. 2000. Psikologi Perkembangan Anak dan Remaja. Bandung: Remaja Rosdakarya.

Zuriah, Nurul. 2008. Pendidikan M oral dan Budi Pekerti dalam Perspektif Perubahan. Jakarta: Bumi A ksara. 
